\title{
Biomass production and carbon balance of a short rotation forestry of Populus deltoides (clone Lux) under two different cutting cycles
}

\author{
Producción de biomasa y balance de carbono en una rotación \\ de Populus deltoides (clon Lux) bajo dos ciclos de corta
}

\author{
Antonio María Cabrera ${ }^{\text {a*, }}$, Cristiano Tozzini ${ }^{b}$, Sergio Espinoza a, Rómulo Santelices a ${ }^{\text {, Fernando Meza }}{ }^{c}$ \\ *Corresponding autor: ${ }^{a}$ Universidad Católica del Maule, Centro de Desarrollo del Secano Interior, \\ Avenida San Miguel 3605, Talca, Chile, phone +56-071-2413728, acabrera@ucm.cl \\ ${ }^{\mathrm{b}}$ Centro Interdipartimentale di Ricerche Agro-ambientali "Enrico Avanzi” via Vecchia di Marina, \\ 6 - 56122 San Piero a Grado (Pisa), Italy. \\ c Universidad Santo Tomás, Facultad de Ciencias Básicas, Departamento de Ciencias Básicas, \\ Mendoza \# 120, Los Ángeles, Chile.
}

\begin{abstract}
SUMMARY
The emissions of green house gases contribute to global warming. Consequently, renewable energies such as solar, wind power, hydropower and bio energy appear as alternatives for reducing these emissions. One promising source of renewable energy is forest biomass, for it is considered to have neutral $\mathrm{CO}_{2}$ balance. The problem is to quantify the amount of $\mathrm{CO}_{2}$ that is emitted for a certain amount of energy generated, compared to the $\mathrm{CO}_{2}$ emitted to generate the same amount of energy from a non-renewable source. In this paper we calculate biomass production and carbon dioxide balance of an eight-year-old Populus deltoides short rotation forestry (SRF) under two cutting cycles (harvesting every two years, biennial and every three years, triennial). We also compare the amount of energy generated per $\mathrm{kg}$ of $\mathrm{CO}_{2}$ emitted in the use of fossil fuels versus the amount of energy generated per kilogram of $\mathrm{CO}_{2}$ emitted. On the one hand, total biomass yield was $12.6 \pm 0.9 \mathrm{Mg} \mathrm{ha}^{-1}$ year $^{-1}$ and $15.1 \pm 1.5 \mathrm{Mg} \mathrm{ha}^{-1}$ year ${ }^{-1}$ for biennial and triennial cutting cycles respectively. On the other hand, total emissions of $\mathrm{CO}_{2}$ for growing a poplar SRF with a cycle of eight year and biennial cutting sequence reached a value of $738.8 \mathrm{~kg} \mathrm{ha}^{-1}$ year ${ }^{-1}$; however, triennial short total emissions are equivalent to $695.5 \mathrm{~kg} \mathrm{ha}^{-1} \mathrm{year}^{-1}$. We concluded that the use of biomass makes a positive contribution to the reduction of greenhouse gases, in particular $\mathrm{CO}_{2}$, reducing emissions almost five times compared with fossil fuels.
\end{abstract}

Key words: carbon dioxide balance, Populus, short rotation forestry, biomass production.

\section{RESUMEN}

Las emisiones de gases de efecto invernadero contribuyen al calentamiento global. En esta situación, las energías renovables como la solar, élica, hidroeléctrica y biomasa, aparecen como una alternativa para reducir estas emisiones. Una prometedora fuente de energía renovable es la biomasa, considerada con un balance de $\mathrm{CO}_{2}$ neutro. El problema es cuantificar el $\mathrm{CO}_{2}$ emitido para una cierta cantidad de energía generada, en comparación con el $\mathrm{CO}_{2}$ emitido para generar la misma cantidad de energía de una fuente no renovable. En este trabajo se calculó la producción de biomasa y el balance de $\mathrm{CO}_{2}$ en una rotación de ocho años de edad de Populus deltoides bajo dos ciclos de corte (bienal y trienal). También se comparó la cantidad de energía generada por kilogramo de $\mathrm{CO}_{2}$ emitido en el uso de combustibles fósiles frente a la cantidad de energía generada por kilogramo de $\mathrm{CO}_{2}$ emitido en el uso de biomasa como energía. El rendimiento total de la biomasa fue de 12,6 $\pm 0,9 \mathrm{Mg} \mathrm{ha}^{-1}$ año $^{-1}$ y 15,1 $\pm 1,5 \mathrm{Mg} \mathrm{ha}^{-1}$ año ${ }^{-1}$ para los ciclos bienal y trienal respectivamente. Las emisiones totales de $\mathrm{CO}_{2}$ fueron de 738,8 $\mathrm{kg} \mathrm{ha}^{-1}$ año $^{-1}$ y $695,5 \mathrm{~kg} \mathrm{ha}^{-1}$ año ${ }^{-1}$ para los ciclos bienal y trienal, respectivamente. Se concluyó que el uso de biomasa constituye una contribución positiva a la reducción de gases de efecto invernadero, en particular $\mathrm{CO}_{2}$, reduciendo las emisiones casi cinco veces en comparación con combustibles fósiles.

Palabras clave: balance de dióxido de carbono, Populus, ciclos cortos de rotación, producción de biomasa.

\section{INTRODUCTION}

During the last years the strong growth of population globally recorded has resulted in a growing need for ener- gy in developed and developing countries (Tlili 2015). The main risk from the growing pressure exerted by mankind on the use of energy resources (i.e. oil, gas, coal) is represented not only because they are finite resources, but also 
for the impact on the environment caused by the use of these resources (ENEA 1999). In fact, the use of fossil fuels, such as gas, produces carbon dioxide $\left(\mathrm{CO}_{2}\right)$; which, in certain concentrations, is considered as one of the main causes of the greenhouse effect, which is the basis of global warming and climate change (IPCC 2006). As the atmospheric concentration of $\mathrm{CO}_{2}$ grows, there is an increasing interest in restraining this growth to minimize potential impacts on the global climate (West and Marland 2002). One of the most promising alternatives for reducing $\mathrm{CO}_{2}$ emissions is the production of biomass energy, specifically lignocellulosic crops that can be used to produce heat and electricity through direct combustion, or biofuel or biogas production through pyrolysis and gasification (Mantineo et al. 2009). Biomass energy, both lignocellulosic and herbaceous, is presented as a sustainable and environmentally friendly source of an alternative energy; in fact the production of energy from renewable sources has a limited environmental impact. In particular, the contribution to the greenhouse effect is extremely small: $\mathrm{CO}_{2}$ emissions related to the stages of conversion processes are almost completely balanced by the $\mathrm{CO}_{2}$ consumption required for the growth of the biomass used as an energy source (Cannell 2002).

One of the main problems associated with the introduction of alternative crops for energy production is to assess the long-term sustainability of these crops. For this purpose, $\mathrm{CO}_{2}$ balances, energy balance and water use efficiency, among others, may represent an optimal tool for sustainability assessment in particular for the energy crops cultivation system, which has to ensure a reduction in $\mathrm{CO}_{2}$ emissions, compared to the use of fossil fuels, i.e., positive $\mathrm{CO}_{2}$ balance.

Regarding the above mentioned, $\mathrm{CO}_{2}$ balance has been widely used (Lewandowski et al. 1995, Cannell 2002, Kaur 2002, Hoosbeek et al. 2006) and it estimates the emissions generated in the whole crop production cycle compared with the $\mathrm{CO}_{2}$ fixed by the plant during its growth. $\mathrm{CO}_{2}$ balance takes into account all the issues arising from the implementation of the different forestry operations; considering not only the emissions produced during the combustion of biomass, but also the emissions generated in input productions (fertilizers, herbicides, etc.). For example, Dornburg et al. (2005), for a poplar SRF held in Poland and the Netherlands with fertilization every four years, obtained $\mathrm{CO}_{2}$ emission values, in the production phase of the crop, in a range of $1,170-1,660 \mathrm{~kg} \mathrm{ha}^{-1} \mathrm{year}^{-1}$. The results in this study demonstrate to be consistent with most of the available data, which indicates a strong relationship between the cutting cycle and the productivity of the stand (Deckmyn et al. 2004). The objective is to estimate the eventual reduction of $\mathrm{CO}_{2}$ emissions through the energy production from biomass compared to the same amount of energy produced from fossil fuel.

This paper hypothesizes that the $\mathrm{CO}_{2}$ balance in an eight-year-old Populus deltoides Marshall (clone Lux) short rotation forestry under two cutting cycles is negative, i.e. the $\mathrm{CO}_{2}$ fixed by the plants is higher than the $\mathrm{CO}_{2}$ emitted in the entire production process.

\section{METHODS}

Study area. The study was conducted at the Centro di Ricerche Agro-ambientali (CIRAA) Enrico Avanzi at Pisa University (Italy). The experimental field is situated in San Piero a Grado, $43^{\circ} 40^{\prime} \mathrm{N}, 10^{\circ} 21^{\prime} \mathrm{E}$ at $5 \mathrm{~m}$ above sea level and $5 \mathrm{~km}$ far from the sea. The soil was a Xerofluvent (clay $20.1 \%$, silt $40.5 \%$, sand $39.4 \%$ ), typical of the lower River Arno, which is an alluvial plain characterized by a superficial water table (1.8 $\mathrm{m}$ deep in the driest conditions) and good nutrient availability (organic matter $1.8 \%$, total nitrogen content $1.3 \mathrm{~g} \mathrm{~kg}^{-1}$, available phosphorus $8.8 \mathrm{mg}$ $\mathrm{kg}^{-1}$ and exchangeable potassium $128.3 \mathrm{mg} \mathrm{kg}^{-1}$ ).

The average climate conditions of the site during the trial are shown in figure 1. During the experimental period (from 2000 to 2008), a considerable variability in rainfall was observed from year to year with a mean annual rainfall of approximately $750 \mathrm{~mm}$ (from 655 to $936 \mathrm{~mm}$ ).

Experimental setup. The experiment began in the year 2000 planting 10,000 plants per hectare; it was conducted in two plots of $5,000 \mathrm{~m}^{2}$ each. In 2002 both plots were harvested and it was in that year when two cutting cycles were chosen (biennial T2, and triennial T3). Each cutting cycle was represented in an individual plot, being each plot the basis for future comparisons. T2 was harvested in 2002, 2004, 2006 and 2008 and T3 was harvested in 2002, 2005 and 2008 (Cabrera et al. 2014). The soil was prepared ahead the planting season (October 1999) by deep plowing $(50 \mathrm{~cm})$, followed by sub soiling with ridge and plow. Then a pre-planting herbicide (Pendimentalin Click ${ }^{\circledR}$ 50, $3 \mathrm{~L} \mathrm{ha}^{-1}$ ) and a fertilization using $600 \mathrm{~kg} \mathrm{ha}^{-1}$ of a generic 8-24-24 fertilizer was applied. In the year 2000 we planted $20 \mathrm{~cm}$ long uprooted P. deltoides (clone Lux) cuttings. The plant density was equivalent to 10,000 plants $\mathrm{ha}^{-1}$ and the planting design was $2 \mathrm{~m} \times 0.5 \mathrm{~m}$. In 2002, the first harvest was made in both plots. The biennial (T2) was harvested in 2002, 2004, 2006 and 2008 and the triennial (T3) in 2002, 2005 and 2008; always at the end of February before the vegetative regrowth. To harvest, a harvesting tookloader-chipper, as well as a trailer carried by a tractor for the collection of chipped material, was used. After each harvest, supplementary fertilization applying $100 \mathrm{~kg} \mathrm{ha}^{-1}$ of nitrogen supplied as urea was applied.

At the end of the experiment (i.e. year 2008) the soil was recovered by removing the stumps with stump cutter and making a deep plowing and sub soiling. We used various types of tractors depending on the operation to perform: $132 \mathrm{~kW}$ of power for plowing and harvesting, $73 \mathrm{~kW}$ to sub soiling and $48 \mathrm{~kW}$ for all the other operations.

Biomass production. At every harvest, the fresh aboveground biomass of the whole plant was assessed. Data were sampled in five transects (5m long, 10 plants) per plot, which were always located within the three central rows of the plot. Biomass samples of each plot were oven 


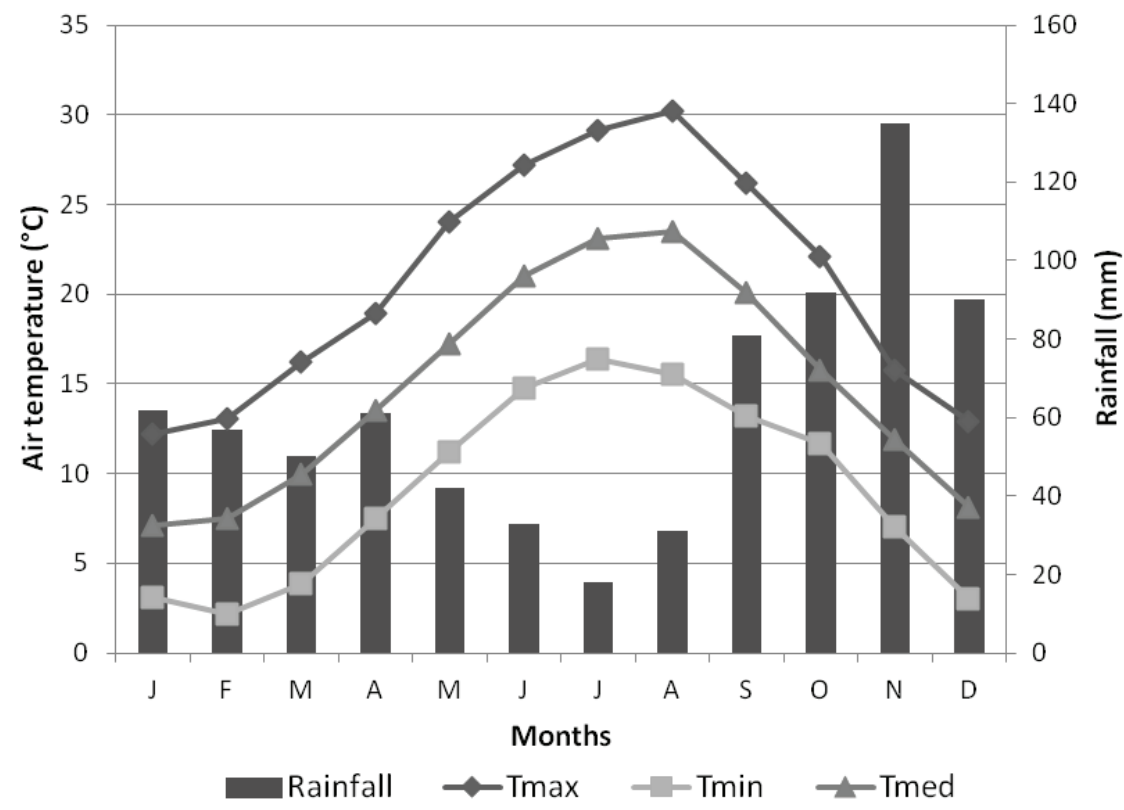

Figure 1. Climate conditions at the field experimental station. $T_{\max }:$ maximum temperature; $T_{\min }: \operatorname{minimum}$ temperature; $T_{\text {med }}:$ medium temperature.

Condiciones climáticas en el sitio de experimentación. $\mathrm{T}_{\max }$ : temperatura máxima, $\mathrm{T}_{\min }$ : Temperatura mínima; $\mathrm{T}_{\text {med }}$ : temperatura media.

dried at $105^{\circ} \mathrm{C}$ (to constant mass) and the dry matter content was determined. Total biomass was calculated by multiplying the average dry weight of the plants of each transects by the plantation density. Average biomass per hectare for each cutting cycle was calculated by averaging the biomass yield in each harvest by the eight years of the trail duration. For dry weight, a Student's t-test was used to compare means under different treatments.

$\mathrm{CO}_{2}$ balance. This study considered $\mathrm{CO}_{2}$ emissions relating to the operations required to grow poplar short rotation forestry and turn harvested biomass into usable solid biofuel (woody chip) in the field. Post processing and the conversion of woodchips were excluded from the analysis. The propagation material $\mathrm{CO}_{2}$ emissions were considered negligible.

The calculation of $\mathrm{CO}_{2}$ balance begins with the calculation of the emissions for the different operations made to the soil and to the crop, starting with fuel and lubricant that characterizes each of these operations. Specific consumption for each of the farming operations were obtained from Bonari et al. (1999), for the same types of operations (table 1) in the same areas. Regarding harvesting, the data have been determined directly during the development of the experiment. The $\mathrm{CO}_{2}$ emissions generated by the inputs (fuel, lubricants, fertilizers, herbicides, etc.) were calculated using coefficients found in literature (table 2).

To compare the $\mathrm{CO}_{2}$ emissions generated with the potential energy obtainable from biomass, the energy output was determined subsequently by multiplying the dry mat- ter yield by the calorific value of the plant material that is considered $18 \mathrm{MJ} \mathrm{kg}^{-1}$ according to Cabrera (2009) and it is in the range of the most recent literature (Carmona et al. 2015). Thus, we are able to calculate the quantity of energy for every $\mathrm{CO}_{2} \mathrm{~kg}$ emitted.

Table 1. Fuel and oil consumption of different agricultural operations and its related $\mathrm{CO}_{2}$ emissions (Bonari et al. 1999).

Consumo de diesel, aceite y emisiones de $\mathrm{CO}_{2}$ de diferentes operaciones agrícolas (Bonari et al. 1999).

\begin{tabular}{|c|c|c|c|c|}
\hline \multirow[b]{2}{*}{ Operation } & & \multicolumn{3}{|c|}{ Consumption } \\
\hline & & $\begin{array}{c}\text { Diesel } \\
\left(\mathrm{kg} \mathrm{ha}^{-1}\right)\end{array}$ & $\begin{array}{c}\text { Lubricant } \\
\left(\mathrm{kg} \mathrm{ha}^{-1}\right)\end{array}$ & $\begin{array}{c}\mathrm{CO}_{2} \text { emissions } \\
\left(\mathrm{kg} \mathrm{ha}^{-1}\right)\end{array}$ \\
\hline $\begin{array}{l}\text { Deep plowing } \\
(50 \mathrm{~cm})\end{array}$ & & 65.0 & 0.36 & 207.2 \\
\hline Subsoiling & & 14.6 & 0.04 & 46.5 \\
\hline Plow & & 50.0 & 0.20 & 180.4 \\
\hline Herbicide & & 7.0 & 0.05 & 22.3 \\
\hline Fertilize & & 7.8 & 0.02 & 24.9 \\
\hline Planting & & 18.7 & 0.04 & 59.6 \\
\hline \multirow[t]{2}{*}{ Harvest } & $\mathrm{T} 2$ & 51.0 & 0.35 & 162.6 \\
\hline & $\mathrm{T} 3$ & 80.0 & 0.45 & 255 \\
\hline Stump cutter & & 6.2 & 0.03 & 19.8 \\
\hline Subsoiling & & 14.6 & 0.04 & 46.4 \\
\hline
\end{tabular}


Table 2. Conversion factors for $\mathrm{CO}_{2}$ emissions of different inputs. Factores de conversión en $\mathrm{CO}_{2}$ de diferentes inputs.

\begin{tabular}{lcl}
\hline Inputs & $\begin{array}{c}\text { Conversion factor } \\
\left(\mathrm{kg} \mathrm{kg}^{-1}\right)\end{array}$ & \multicolumn{1}{c}{ Reference } \\
\hline Fuel & 3.19 & IPCC (2006) \\
Lubricant & 2.95 & IPCC (2006) \\
$\mathrm{N}$ & 3.15 & West and Marland (2002) \\
$\mathrm{P}_{2} \mathrm{O}_{5}$ & 6.04 & West and Marland (2002) \\
$\mathrm{K}_{2} \mathrm{O}$ & 4.39 & West and Marland (2002) \\
Herbicide & 15.92 & West and Marland (2002) \\
\hline
\end{tabular}

\section{RESULTS}

Biomass production. The annual average production in the study of the complete cycle of $P$. deltoides clone Lux differs among treatments, being T3 the most productive cutting cycle (figure 2 and table 3 ).

Lower yields in the period 2004-2006 may be because rainfall in that period was lower than the average rainfall.

$\mathrm{CO}_{2}$ balance. The calculation of $\mathrm{CO}_{2}$ emissions for the poplar cultivation with biennial and triennial cutting cycles has been made considering all the emissions involved from planting to harvesting. Total emissions of $\mathrm{CO}_{2}$ for growing a poplar SRF with a cycle of eight years and biennial cutting cycle reach a value of $5,910.4 \mathrm{~kg} \mathrm{ha}^{-1}$, equivalent to $738.8 \mathrm{~kg} \mathrm{ha}^{-1}$ year $^{-1}$; whereas, for a triennial cutting cycle in a cycle of eight years, the value reached was $5,564.3 \mathrm{~kg}$ $\mathrm{ha}^{-1}$, equivalent to $695.5 \mathrm{~kg} \mathrm{ha}^{-1}$ year $^{-1}$. From these results it can be said that growing poplar biomass with triennial cutting cycles involves lower $\mathrm{CO}_{2}$ emissions compared with growing biomass with biennial cutting cycles.

Considering the yield and the potential energy generated by the biomass, it can be said that the energy produced is $224.1 \mathrm{MJ} \mathrm{kg}^{-1}$ of $\mathrm{CO}_{2}$ and $297.6 \mathrm{MJ} \mathrm{kg}^{-1}$ of $\mathrm{CO}_{2}$, respectively for $\mathrm{T} 2$ and $\mathrm{T} 3$, being $\mathrm{T} 3$ the most energy productive cutting cycle.

\section{DISCUSSION}

This long-term trial revealed that different harvesting cycles can affect parameters such as biomass yield and carbon balance. The results in this study demonstrate to be consistent with most of the available data, which indicate a strong relationship between the cutting cycle and the productivity of the stand (Deckmyn et al. 2004). In fact, for biannual cutting cycles Rafaschieri et al. (1999) obtained variable yields between 16 and $20 \mathrm{Mg} \mathrm{ha}^{-1}$ year-1 while for short cutting cycles varying between three and five years, Kauter et al. (2003) using Populus sp., obtained between 10 and $12 \mathrm{Mg} \mathrm{ha}^{-1}$ year $^{-1}$ yield.

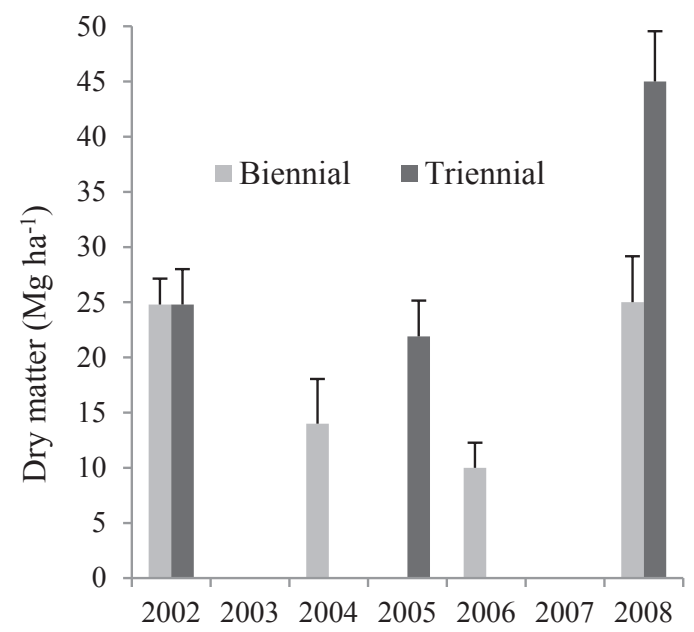

Figure 2. Populus deltoides clone Lux, biomass production during the period 2000-2008.

Producción de biomasa en el cultivo de Populus deltoides clon Lux en el periodo 2000-2008.

In our case, $\mathrm{CO}_{2}$ emissions resulting from the implementation of the various farming operations are minor and contribute in reducing the greenhouse effect caused by the production of energy with other non-renewable fossil fuels. The results of this study can be compared with those obtained by Dornburg et al. (2005) for a poplar SRF held in Poland and the Netherlands with fertilization every four years, obtaining values of $\mathrm{CO}_{2}$ emissions in a range of $1,170-1,660 \mathrm{~kg} \mathrm{ha}^{-1}$ year $^{-1}$. In another study, Bacenetti and Fiala (2011), in a poplar SRF in northern Italy with twoyear cutting cycle and $18 \mathrm{Mg} \mathrm{ha}^{-1}$ year ${ }^{-1}$ yields, calculated emissions equivalents to $1,179 \mathrm{~kg} \mathrm{ha}^{-1}$ year-1 of $\mathrm{CO}_{2}$; which is consistent with those results obtained in this study.

From the analyses of the different cutting cycles for a poplar SRF emerges that taking longer cutting cycles consents lower emissions compared with shorter cycles. Comparing these results with others reported by Dubuisson and Sintzoff (1998), it can be shown that depending on the level of intensification, values regarding $\mathrm{CO}_{2}$ emissions vary from 101-160 $\mathrm{MJ} \mathrm{kg}^{-1}$ of $\mathrm{CO}_{2}$. Whereas the results reported by Matthews (2001) showed mean values of 209.8 MJ $\mathrm{kg}^{-1}$ of $\mathrm{CO}_{2}$. In the latter study, the calculation of overall energy and carbon budgets required a set of 'standard' assumptions about practices and resultant energy inputs to be made. These standard assumptions accounted for all activities involved in production and delivery of biofuel within the immediate vicinity of the farm $(3.2 \mathrm{~km})$. The carbon emissions coefficient exhibited similar sensitivity to input assumptions (Matthews 2001).

Depending on the limits analyzed in the cropping system, emissions will be higher or lower. What is clear is that there is a significant reduction in emissions when producing the same amount of energy with a renewable energy 
Table 3. Harvest number, average dry yield $( \pm \mathrm{SD}), \mathrm{CO}_{2}$ emissions and energy produced by poplar SRF for each harvesting cycle (T2 and T3, biennial and triennial cutting cycle, respectively). In the same column different letters stand for significant differences $(P \leq 0.05)$.

Número de cosechas, producción media de biomasa seca $( \pm \mathrm{SD})$, emisiones de $\mathrm{CO}_{2}$ y energía producida para el cultivo de álamo en cada ciclo de corta (T2 y T3, corta bienal y trienal respectivamente). En la misma columna, letras diferentes implican diferencias significativas $(P \leq 0,05)$.

\begin{tabular}{|c|c|c|c|c|}
\hline \multirow[b]{2}{*}{ Treatment } & \multicolumn{4}{|c|}{ Parameters } \\
\hline & $\begin{array}{l}\text { Harvest } \\
\text { number }\end{array}$ & $\begin{array}{l}\text { Average dry yield } \\
\left(\mathrm{Mg} \mathrm{ha}^{-1} \text { year }^{-1}\right)\end{array}$ & $\begin{array}{l}\mathrm{CO}_{2} \text { emissions } \\
\left(\mathrm{kg} \mathrm{ha}^{-1} \text { year }^{-1}\right)\end{array}$ & $\begin{array}{l}\text { Energy produced } \\
\left(\mathrm{MJ} \mathrm{ha}^{-1} \text { year }^{-1}\right)\end{array}$ \\
\hline $\mathrm{T} 2$ & 3 & $9.2 \pm 0.9 b$ & 738.8 & 165.6 \\
\hline T3 & 4 & $11.5 \pm 1.5 \mathrm{a}$ & 695.5 & 207.0 \\
\hline
\end{tabular}

source instead of fossil energy source. To quantify the benefits of renewable energy biomass derived from a poplar SRF with biennial and triennial cutting cycles, we have compared the amounts of $\mathrm{CO}_{2}$ emitted by the system under study with the amounts released with the use of fossil fuels (table 4). Analyzing table 4, it can be seen how the energy produced per kilogram of $\mathrm{CO}_{2}$ emitted is much higher in poplar biomass production as an energy source than in the use of any other source of fossil energy. Energy production from biomass is more sustainable, in terms of $\mathrm{CO}_{2}$ emissions, than the use of fossil energy. These results are similar to those obtained by Sevigne et al. (2015) in poplar short rotation forestry in Girona (Spain).

\section{CONCLUSIONS}

The poplar SRC is one of the most promising woody species that can be grown in a Mediterranean climate. The study shows that the energy production obtained is higher than the energy needed for the whole productive process,

Table 4. Energy (MJ) produced per kilogram of $\mathrm{CO}_{2}$ emitted from different energy sources and for a poplar SRF with biennial (T2) and triennial (T3) cutting cycles.

Energía producida por cada kilogramo de $\mathrm{CO}_{2}$ emitido por diferentes fuentes de energía y para el cultivo de álamo con fines energéticos con turnos de corta bienal (T2) y trienal (T3).

\begin{tabular}{|c|c|c|}
\hline Energy source & $\begin{array}{l}\mathrm{MJ} \text { produced for } \\
\mathrm{CO}_{2} \mathrm{~kg} \text { emitted }\end{array}$ & Reference \\
\hline $\mathrm{T} 2$ & 224.1 & This study \\
\hline $\mathrm{T} 3$ & 297.6 & This study \\
\hline Coal & 73.3 & $\begin{array}{l}\text { U.S. Department of } \\
\text { Energy } 2013\end{array}$ \\
\hline Gasoline motor & 54.5 & $\begin{array}{l}\text { U.S. Department of } \\
\quad \text { Energy } 2013\end{array}$ \\
\hline Natural gas & 72.9 & $\begin{array}{l}\text { U.S. Department of } \\
\quad \text { Energy } 2013\end{array}$ \\
\hline Kerosene & 53.5 & $\begin{array}{c}\text { U.S. Department of } \\
\text { Energy } 2013\end{array}$ \\
\hline
\end{tabular}

considering that the clone used is not specific for biomass production. On the other hand, generated $\mathrm{CO}_{2}$ emissions are low, especially when compared to the emissions generated to produce energy from other fossils energy sources, reducing emissions almost five times. Furthermore, the use of renewable sources of energy contributes in mitigating the $\mathrm{CO}_{2}$ emissions. Another essential point result suggests that producing energy from poplar biomass can be a sustainable alternative in terms of carbon balance.

As it can be seen, it can be concluded that the use of biomass makes a positive contribution to the reduction of greenhouse gases, in particular $\mathrm{CO}_{2}$. Finally, the methodology used for calculating the carbon balance can be very useful if applied to any other energy crop.

\section{ACKNOWLEDGEMENTS}

We are indebted with Jorge Cuevas Aburto, English coordinator, and Felix W. Doughty, English professor, both from Universidad Santo Tomás, for their valuable corrections of English.

\section{REFERENCES}

Bacenetti J, M Fiala. 2011. Short Rotation Coppice in Italy: a model to asses economic, energetic and environmental performances of different crop systems. In Proceedings of World Renewable Energy Congress. Linköping, Sweden, 8-13 May 2011.

Bonari E, N Silvestri, S Pampana. 1999. Sisco: a pratical tool to assess alternative cropping systems' performances. In Proceedings of International Symposium Modelling Cropping Systems. 1999 June 21-23. Lleida, Spain. p. 285-286.

Cabrera A. 2009. Confronto fra colture "dedicate" per la produzione di biomassa a destinazione energetica in ambiente mediterraneo. PhD Thesis. Pisa, Italy. LAND LAB Scuola Superiore Sant'Anna - Universitá di Pisa. 173 p.

Cabrera A, C Tozzini, S Espinoza, R Santelices, E Bonari. 2014. Cálculo del balance energético de una plantación de Populus deltoides clon Lux con fines energéticos en un sitio con ambiente mediterráneo. Bosque 35(2): 133-139.

Cannell MGR. 2002. Carbon sequestration and biomass energy offset: Theoretical, potential and achievable capacities globally, in Europe and the UK. Biomass and Bioenergy 24 (2): 97-116. 
Deckmyn G, I Laureysens, J Garcia, B Muys, R Ceulemans. 2004. Poplar growth and yield in short rotation coppice: model simulations using the process model SECRETS. Biomass and Bioenergy 26: 221-227.

Dornburg V, G Termeer, APC Faaij. 2005. Economic and greenhouse gas emission analysis of bioenergy production using multi-product crops-case studies for the Netherlands and Poland. Biomass and Bioenergy 28: 454-474.

Dubuisson X, I Sintzoff. 1998. Energy and $\mathrm{CO}_{2}$ balances in different power generation routes using wood fuel from short rotation coppice. Biomass and Bioenergy 15: 379-390.

ENEA (Agenzia Nazionale per le Nuove Tecnologie, L'energia e lo Sviluppo Economico Sostenibile, IT). 1999. Libro Bianco per la valorizzazione energetica delle fonti rinnovabili. Consulted Jul. 2, 2013. Available in http://www.regione. sicilia.it/industria/use/Documenti\%20ufficiali\%20energia/ Nazionali/Libro\%20bianco\%20fonti\%20rinnovabili\%20 Italia\%20Aprile\%201999.pdf

Hoosbeek M, Y Li, G Scarascia-Mugnozza. 2006. Free atmosferic $\mathrm{CO}_{2}$ enrichment (FACE) increased labile and total carbon in the mineral soil of a short rotation poplar plantation. Plant and Soil 281: 247-254.

IPCC (Intergovernmental Panel on Climate Change, CH). 2006. Guidelines for National Greenhouse Gas Inventories. Consulted Jul. 2, 2013 Available in http://www.ipcc-nggip.iges. or.jp/public/2006gl/

Kaur B, SR Gupta, G Singh. 2002. Carbon storage and nitrogen cycling in silvopastoral systems on a sodic soil in northwestern India. Agroforestry Systems 54: 21-29.

Kauter D, I Lewandowski, W Claupein. 2003. Quantity and qua- lity of harvestable biomass from Populus short rotation coppice for solid fuel use - a review of the physiological basis and management influences. Biomass and Bioenergy 24(6): 411-427.

Lewandowski I, A Kicherer, P Vonier. 1995. $\mathrm{CO}_{2}$-balance for the cultivation and combustion of Miscanthus. Biomass and Bioenergy 8(2): 81-90.

Mantineo M, GM D’Agosta, V Copani, C Patane, SL Cosentino. 2009. Biomass yield and energy balance of three perennial crops for energy use in the semi-arid Mediterranean environment. Field Crops Research 114: 204-213.

Matthews RW. 2001. Modelling of energy and carbon budgets of wood fuel coppice systems. Biomass and Bioenergy 21 (1): $1-19$

Rafaschieri A, M Rapaccini, G Manfrida. 1999. Life cycle assessment of electricity production from poplar energy crops compared with conventional fossil fuels. Energy Convertion and Management 40: 1477-1493.

Sevigne E, CM Gasol, F Brun, L Rovira, JM Pagés, F Camps, J Rieredevall, X Gabarrell. 2011. Water and energy consumption of Pupulus spp. bioenergy systems: A case study in Southern Europe. Renewable and Sustainable Energy Reviews 15: 1133-1140.

U.S. Department of Energy. 2013. Independent statistic and analysis. Consulted Jul.3, 2013. Available in http://www. eia.gov/tools/faqs/faq.cfm?id $=73 \& \mathrm{t}=11$.

West TO, G Marland. 2002. A synthesis of carbon sequestration, carbon emissions, and net carbon flux in agriculture: Comparing tillage practices in the United States. Agriculture, Ecosystems and Environment 91(1-3): 217-232. 